\section{IJ§ER}

ISSN: 2149-5939
International Journal of Social Sciences and Education Research

Online, http://dergipark.gov.tr/ijsser

Volume: $2(1), 2016$

\title{
Croatian academics' attitudes on the importance of academic profession competencies $^{1}$
}

\author{
Marko Turk ${ }^{2} \quad$ Jasminka Ledić ${ }^{3}$
}

Received Date: 14 / $10 / 2015$

Accepted Date: 31/12/2015

\begin{abstract}
Academic profession is faced with changes and challenges in social environment that occur in the global area of higher education. These challenges call for (re)defining the existing and introducing new competencies for performing everyday academic duties. The research findings presented in this paper, attempt to answer the research question What are the competencies academics need at the start of their senior academic career? The research was conducted on a sample of 1130 academics of all academic positions from seven public universities in Croatia. The online survey examined the attitudes about how important each competency is to successfully perform the role of a senior academic as well as their assessment of the mastery of each competency. The evaluation scale contained 41 items - academic profession competencies. This paper will present the results of the rankings on the scale evaluating the importance of academic profession competencies and corresponding discussion about new research questions that has been opened. Some of these questions are related to discussions on approaches to acquiring new and/or redefining existing competencies of the academic profession and systems of support for acquiring and redefining academic profession' competencies.
\end{abstract}

Keywords: Academic profession, Academic profession competencies, (Senior) Academics

\section{Introduction}

Changes in the (social) environment, to which academic profession did not remain immune, are in strong correlation with the transformation of academic affairs and activities in the last few decades. The former core activities that used to mark academic profession - teaching and research, are becoming only a part of a wide range of activities. Universities and academics are in constant interaction with a number of stakeholders from the external (social) environment - students and their parents, politicians, business sector and the labour market, the economy, previous levels of education, public and private institutions. Purcell (2008) points out that society has great expectations from academics, and classifies those expectations as - contribution to the growth of the knowledge economy; development and maintenance of large and advanced knowledge base; high quality education and training; lifelong learning; excellence in research and counselling; implementation of an international, multicultural education; promotion of equal opportunities and access to higher education. In addition to the above mentioned, academics are also faced with pressures and demands in connection with academic progress on everyday basis. In such conditions of academic staff is expected to develop new competencies that would enable the fulfilment of

\footnotetext{
${ }^{1}$ This paper is a part of a research project "Academic Profession Competencies Profile: Between new Requirements and Possibilities" (APROFRAME), supported by Croatian Science Foundation, contract No I-2148-2014.

${ }^{2}$ Postdoctoral researcher, University of Rijeka, Faculty of Humanities and Social Sciences, Department of Education, e: marko.turk@fffri.uniri.hr

${ }^{3}$ Tenured full professor, University of Rijeka, Faculty of Humanities and Social Sciences, Department of Education, e: jledic@ffri.hr
} 
Turk, M., Ledić, J. (2016). Croatian academics' attitudes on the importance of academic profession competencies. International Journal of Social Sciences and Education Research, 2 (1), 116-130.

the new requirements and the performance of new activities (Musselin, 2007). Studies that examined changes in the academic profession and (new) requirements that academics are expected to meet (Neave, 1983; Altbach \& Davis, 1999; Altbach, 2000; Deem, 2001; Altbach, 2002; Kelly \& Murphy, 2007; Altbach, Reisberg \& Rumbley, 2009; Turk, 2015) suggest that new, multidimensional and sometimes contradictory expectations are being created in addition to the basic academic activities - teaching and research (Ledić, 2012). All this led to the need of redefining and developing (new) competencies that have not been requested until now or have not been considered significant and important in academic work.

Teaching and research are traditionally viewed as core academic activities, which are considered the most important in the system of academics' advancement. Both those activities, that is, their interconnectedness and distinctness, have been the subject of numerous research studies (Ramsden \& Moses, 1992; Braxton 1993, Bess, 1998; Colbeck, 2002, McInnis, 2000; Kuh \& Hu, 2001; Brew, 2006; Kogan \& Teichler, 2007; Locke \& Teichler, 2007). In addition to better understanding the nature of academic activities, the said research studies are also connected with numerous institutional and governmental or political practices (Ćulum, Rončević \& Ledić, 2013).

Observed from a quantitative point of view, most of the researches and debates revolve around teaching competencies of the academic profession (Inlow 1956; Elton, 1986, 1992, 2001; Knight, 1995; Rychen \& Salganik 2003; Koster \& Dengerink, 2008; Henard \& Roseveare, 2012). Recent research studies (Kroeber, 2007; Marton, 2007; Donaldson, 2013) suggests that teachers in the 21 st century, regardless of educational level, must enable future generations to make progress in an environment of rapid, lasting and fundamental changes, but at the same time they must use those potentially far-reaching challenges that systems of teaching and learning are faced with. "Teachers are important" is the title of OECD's report for 2005 which summarizes a wide range of evidence that suggest that good teachers are one of the most important factors influencing the successful of learning. Likewise, in 2007, corporation McKinsey published a report (McKinsey, 2007) in which it emphasizes the importance of good teachers in the most productive educational systems in the world. Concluding passages of the report specifically point out that the quality of the education system cannot surpass the quality of a teacher.

In addition to mentioned researches, projects and recommendations on the level of the European education policy (for example: DeSeCo project (OECD, 2005), European Language Teacher Education (Kelly \& Grenfell, 2002; Kelly et al., 2004), TALIS research, Common European Principles for Teacher Competence and Qualifications (2004)), point to a wide range of responsibilities and competencies that academics need in order to successfully teach. In addition, they confirm the conclusions from the document by the European Commission - Supporting the teaching Profession for Better Learning Outcomes (2012) that requirements for the development of teaching competencies are always present, but that they are also under the constant influence of social and technological.

Although research competencies haven't produced the same interest as teaching competencies, they too were discussed. One of the significant contributions to the structuring and systematization of research competencies was given by a document of a more recent date entitled Skills and competencies needed in the research field objectives 2020 (2010). This document highlights significant changes that are taking place in the European research area, which haven't bypassed research institutions. Powerful globalization pressures, increased openness of the research market, a strong mobility trend among researchers, insistence on the increased interdisciplinarity and on 
Turk, M., Ledić, J. (2016). Croatian academics' attitudes on the importance of academic profession competencies. International Journal of Social Sciences and Education Research, 2 (1), 116-130.

the cooperation of various research teams, as well as political investments in research and innovation are just some of the factors that influence changes in European research policies. Likewise, UNESCO World Report - Towards Knowledge Societies (2005), in the chapter on research and the relationship between science and the public, highlights the disparities in research fields, the spreading and almost complete disappearance of boundaries of research information, as well as the development of new research fields and raises the issue of intellectual ownership. As a consequence of dealing with such changes, the question arises what are the knowledge, skills and abilities that characterize an exceptional researcher.

International discussions, research studies and recommendations on the level of educational policies on teaching competencies, and to a lesser extent, research competencies of academics, have been producing new lists of competencies and have been upgrading the existing ones. In addition to teaching and research competencies, and given the changes in the academic profession, requirements for the development of new academic competencies have started to appear in recent years. This refers to the development of competencies resulting from the requirement for the advancement of the third mission of universities (Boyer, 1990, 1996; Macfarlane, 2005, 2007; Ledić, 2007; Cantor, 2010; Ćulum \& Ledić, 2010; Ćulum, 2012), as well as for those aimed at leadership in the research and higher education (Hoff, 1999; Nelson, 2003; Smith, 2004; Spendlove, 2007; Crosthwaite, 2010; Dávila Quintana, Mora Ruiz \&Vila Lladós, 2011; Potgieter, Basson \& Coetzee, 2011).

Under the influence of external pressures and expectations that universities are facing with for the purpose of a stronger contribution to society or to the knowledge economy (Brennan et. all, 2007), in the last two decades debates have been increasing. The debates are focused on the analysis and better understanding of relationships and various modalities of cooperation between universities and the environment in which they operates. Most authors agree that the concept of the third mission examines the role of the university and its contribution to local, regional and national development (Goddard \& Chatterton, 2003; Arbo \& Benneworth, 2006; Benneworth \& Hospers, 2007).

In research studies, the fourth group of academic profession' competencies is represented by a group of so-called leadership competencies or the competencies of leadership in higher education (Hoff, 1999; Burkard et al., 2005; Spendlove, 2007; Quintana, Mora Ruiz \& Vila Lladós, 2011). Based on the analysis of discussions on this group of competencies, it can be concluded that the group of leadership competencies in higher education has an important place in the debate about the academics' competencies and that it was redefined over the years and steered towards the growing number of academics. From the initial exclusive focus on the leaders of higher education institutions, leadership competencies in higher education are also becoming increasingly focused on a wider range of academics at different stages in their careers.

Research on the academic profession competencies in Croatia were predominantly focused on the group of teaching competencies. Based on the analysis of the mentioned research studies, it can be concluded that the discussions of various authors (Smith, 1996, 2001; Calin, 2004; Munjiza \& Lucas, 2006; Ledić, 2009; Vizek Vidović, 2009; Rački, Peko \& Varga, 2010) can be reduced to two key challenges: the need to revise legislative regulations on the academic promotion proceedures, which would result in achieving a equally evaluation of their teaching and research work; and the need to invest in the academic development programmes. 
Turk, M., Ledić, J. (2016). Croatian academics' attitudes on the importance of academic profession competencies. International Journal of Social Sciences and Education Research, 2 (1), 116-130.

For many years, Croatian research area was deprived of results and discussions on academics' research competencies, which would examine those competencies in a wider context. However, in recent years, a couple of research studies did appear in the national research area which examined the position and academic promotion of young researchers. Those studies (Brajdić Vukovic, 2012,2013 ) deal with the issues of research competencies of young researcher in a wider context. Particularly noteworthy is the lack of formal system for the support and development of research competencies of young researchers, as well as the lack of formal support for their overall professional development.

In the context of the academics third mission competencies, studies predominantly aim to introduce the concept in the national research area (Ledić, 2007; Ćulum 2009; Ćulum \& Ledić, 2010; Ćulum, 2012), explore academics' attitudes regarding the third mission (Ćulum, 2012; Ćulum \& Ledić, 2011; Ćulum, Ledić \& Rončević, 2013) and, in a somewhat wider context, social dimensions in higher education (Puzić, Doolan \& Dolenec, 2006, Farnell \&Smith, 2010; Farnell et al., 2013). On the other hand, the determinants of leadership competencies in higher education are represented in the context of analysis and discussion regarding the governance in higher education (Smith, Ledić \& Rafajac, 2002; 2003; 2007) and, to somewhat lesser extent, analysis and discussions regarding the quality management systems in higher education (Ledić 1994; Lazibat, 2005).

An overview of various determinants of competencies suggests that dispersed and great expectations from the academic profession represent a research challenge in the structuring and operationalization of the academic profession competencies. In that context, it is necessary to take into account not only particularities of individual competencies approaches or groups of competencies specific to a particular profession, but also the particularities of national environments and conditions in which that profession develops and operates. At the same time, directions of current education policies in the European and national environment reveal that Croatian academics too will be expected to meet the requirements for the development of (new) set of competencies ${ }^{1}$. In this context, (re)defining and profiling of existing and new competencies of the academic profession becomes a question par excellence in the academic community in Croatia.

\section{Research methodology, findings and discussion}

So far the area of comprehensive discussion about the academic profession' competencies in the national research area hasn't produced a significant interest of Croatian researchers. The analysis of literature reveals that authors draw attention to the differences in the levels of the academic profession, especially to the differences between junior and senior academics, strenuousness of their responsibilities and job descriptions (Teichler, 1996; Höhle \& Teichler, 2013; Fumasoli \& Gostelac, 2015). Höhle and Teichler (2013) draw attention to the longevity of the period required for the process of learning and maturing in the academic profession. Therefore, it should be assumed that it is not possible to speak of a unique set of competencies that would apply to all academic levels.

\footnotetext{
1 For example, in the national research area, a document entitled Strategy for Education, Science and Technology $(2013,108)$ emphasizes that the role of higher education teachers - representatives of the academic profession - has changed in society and that it includes "... the four segments of activities: teaching (educational); research/artistic; organizational, managerial and professional activities in academic bodies; engagement in the third mission of higher education institutions (activity aimed at contributing to the development and improvement of the community)."
} 
Turk, M., Ledić, J. (2016). Croatian academics' attitudes on the importance of academic profession competencies. International Journal of Social Sciences and Education Research, 2 (1), 116-130.

This research seeks to answer the question what are the competencies an academic should have at the start of his/her senior academic career. When collecting research findings for the purpose of answering the raised research question, the attitudes of academics regarding the importance of competencies of the academic profession are of the utmost importance. Therefore, the objective of this part of research ${ }^{1}$ is to examine the attitudes of academics on the importance of each competencies for the successful accomplishment of their academic activities at the start of their senior academic career.

Research method in this research was an on-line survey, and the research instrument used was a survey questionnaire ${ }^{2}$. Evaluation was carried out on a classic Likert-type scale, with competencies described as being of 1 - very small importance, 2 - small importance, 3 - average importance, 4 - great importance, 5 - extremely great importance. A total of 1130 respondents participated in the research from seven Croatian public universities, which is between 10 and $13 \%$ of the total population. The data were processed using the Statistical Package for the Social Sciences (IBM SPSS Statistics 20.0). In this paper, we will present the results of descriptive statistics - the mean and standard deviation, as well as answer percentages on a Likert-type scale.

Since the literature on the academic profession competencies varies greatly, arranging competencies according to their thematic groups was a research challenge. Competencies were finally arranged into five thematic groups - teaching competencies ${ }^{3}$, research competencies ${ }^{4}$, third mission competen$\operatorname{cies}^{5}$, leadership competencies in higher education ${ }^{6}$ and general (academic) competencies ${ }^{7}$. ${ }^{1}$ Research results presented in this paper are part of the research on competencies of the academic profession, carried
out as part of the project "Academic Profession Competencies Profile: Between new Requirements and Possibilities"
(APROFRAME), supported by Croatian Science Foundation, contract No I-2148-2014.
${ }^{2}$ The survey questionnaire contained a preamble and three content unit. The first unit contained demographic infor-
mation defined on the basis of independent research variables - titles, fields, universities, gender and age. The second
unit was the scale for the evaluation of the importance of particular competencies for the successful performance of the
successful accomplishment of their academic activities at the start of their senior academic career. The third unit is an
evaluation scale of their level of mastery over given competencies up to their current academic career level. For the
purposes of this paper, results obtained based on the analysis of answers from the second unit of the survey question-
naire shall be used.
${ }^{3}$ Developing curricula; Understanding and the application of theories that learning and teaching processes are based
on; Setting clear objectives and results in the process of teaching and learning; Planning and carrying out teaching;
Applying various methods of teaching harmonized with learning results; Applying active learning techniques in the
teaching process; Creating environment that will encourage students to learn; Applying various procedures of assess-
ment and evaluation of students' success aligned with learning results; Applying research findings in teaching; Using
e-learning and its integration in teaching; Adjustment of the teaching process to students with special needs; Monitoring
and advising younger colleagues in relation to teaching work; Introducing changes in the curricula.

${ }^{4}$ Knowledge in the field of research methodology and statistical data processing; Using efficient strategies of searching through research and profession-related literature; Working in an interdisciplinary environment; Using efficient strategies of critical assessment and analysis of scientific literature; Familiarity with the basic principles of scientific writing and publishing; Monitoring and advising younger colleagues in relation to research work; Implementing review procedures in one's own research field; Familiarity with program/project management (writing, applying and managing programs/projects); Familiarity with financing opportunities for projects in the field of one's own research interest; Creating and maintaining (international) research networks.

${ }^{5}$ Educating students as social responsible and active citizens; Implementation of projects which are significant in terms of community's needs; Participation in volunteer and philanthropic programs and activities in the community; Encouraging students to participate in volunteer programs and programs that contribute to the development of the community; Participating in pubic discussions of general social importance from the professional perspective; Cooperation with the civil sector

${ }^{6}$ Familiarity with strategic planning principles; Familiarity with negotiation and conflict resolution principles; Managing financial resources of the institution/department/course; Defining ethical values of the institution/department/course; Introducing innovations and changes in the work of the institution/department/course

${ }^{7}$ The group of general academic competencies consists of competencies that appeared in theoretical descriptions of all previous groups of competencies. In order to avoid repeating the same items, a new group of competencies was formed

ISSN: 2149-5939 
Turk, M., Ledić, J. (2016). Croatian academics' attitudes on the importance of academic profession competencies. International Journal of Social Sciences and Education Research, 2 (1), 116-130.

Table 1 shows academic profession competencies based on the estimates of their importance. Given the arithmetic mean of each individual item, it is evident that respondents estimate individual competencies as having a relatively high importance ${ }^{1}$. That is not surprising since respondents were offered competencies that should be relevant to the academic profession according to the literature in this field.

Table 1 reveals that respondents evaluated the following competencies as the most important ones: General IT literacy (Windows, Microsoft Office, Internet, e-mail) $(\mathrm{M}=4.71, \mathrm{SD}=0.53)$; Oral and written communication in the mother tongue $(\mathrm{M}=4.68, \mathrm{SD}=0.56)$; Planning and carrying out teaching ( $\mathrm{M}=4.42, \mathrm{SD}=0.75)$; Familiarity with the basic principles of scientific writing and publishing $(\mathrm{M}=4.41, \mathrm{SD}=0.73)$; and the Using efficient strategies of searching through research and profession-related literature $(\mathrm{M}=4.35, \mathrm{SD}=0.73)$.

If we compare the estimates of respondents with predefined groups of competencies, it can be observed that the top five most important competencies are these from the group of general academic competencies (General IT literacy and Oral and written communication in the mother tongue), teaching competencies (Planning and performing teaching) and research competencies (Familiarity with the basic principles of scientific writing and publishing and Using efficient strategies of searching through research and profession-related literature).

Table 1. The estimate of importance of academic profession competencies

\begin{tabular}{|l|l|c|c|c|c|c|}
\hline \multicolumn{1}{|c|}{ COMPETENCIES } & $\mathbf{1 + 2}$ & $\mathbf{3}$ & $\mathbf{4 + 5}$ & M & SD \\
\hline 1. & $\begin{array}{l}\text { General IT literacy (Windows, Microsoft Office, Internet, } \\
\text { e-mail) }\end{array}$ & 0.1 & 3.5 & 96.3 & 4.71 & 0.53 \\
\hline 2. & Oral and written communication in the mother tongue & 0.3 & 3.2 & 96.5 & 4.68 & 0.56 \\
\hline 3. & Planning and carrying out teaching & 2.2 & 6.5 & 91.2 & 4.42 & 0.75 \\
\hline 4. & $\begin{array}{l}\text { Familiarity with the basic principles of scientific writing } \\
\text { and publishing }\end{array}$ & 2.0 & 7.8 & 90.2 & 4.41 & 0.73 \\
\hline 5. & $\begin{array}{l}\text { Using efficient strategies of searching through research and } \\
\text { profession-related literature }\end{array}$ & 1.5 & 10.4 & 88.2 & 4.35 & 0.73 \\
\hline 6. & Presentation skills & 1.4 & 9.7 & 88.9 & 4.33 & 0.72 \\
\hline 7. & $\begin{array}{l}\text { Oral and written communication in at least one world lan- } \\
\text { guage }\end{array}$ & 2.0 & 11.5 & 86.6 & 4.30 & 0.76 \\
\hline 8. & Familiarity with ethical principles in teaching and research & 3.6 & 11.8 & 84.6 & 4.28 & 0.84 \\
\hline 9. & $\begin{array}{l}\text { Setting clear objectives and results in the process of teach- } \\
\text { ing and learning }\end{array}$ & 2.0 & 12.6 & 85.5 & 4.25 & 0.76 \\
\hline 10. & Educating students as social responsible and active citizens & 4.0 & 15.6 & 80.4 & 4.12 & 0.83 \\
\hline 11. & $\begin{array}{l}\text { Constant professional development and personal growth } \\
\text { planning in fundamental academic activities }\end{array}$ & 3.3 & 17.3 & 79.5 & 4.11 & 0.81 \\
\hline 12. & Woking in interdisciplinary environment & 5.4 & 16.3 & 78.4 & 4.08 & 0.91 \\
\hline 13. & Creating environment that will encourage students to learn & 2.8 & 18.5 & 78.8 & 4.07 & 0.79 \\
\hline 14. & Applying research findings in teaching & 7.2 & 17.4 & 75.4 & 4.00 & 0.94 \\
\hline
\end{tabular}

the content of which corresponding to competencies entitled general academic competencies - Oral and written communication in the mother tongue; Leading teams and individuals; Oral and written communication in at least one world language; General IT literacy (Windows, Microsoft Office, Internet, e-mail); Presentation skills; Constant professional development and personal growth planning in fundamental academic activities; Cooperation with the public sector and economy (institutions and companies from the related field); Familiarity and the application of fundamental legal documents (acts, regulations...) in the area of science and higher education; Identifying and monitoring recent changes in educational and research policies; Having basic knowledge about intellectual ownership; Familiarity with ethical principles in teaching and research.

${ }^{1}$ Arithmetic means range from the lowest $(\mathrm{M} 2,89)$ to the highest $(\mathrm{M}=4.71)$, where 28 competencies were evaluated as being of great importance (ranging from $\mathrm{M}=3.54$ to $\mathrm{M}=4.42$ ). 
Turk, M., Ledić, J. (2016). Croatian academics' attitudes on the importance of academic profession competencies. International Journal of Social Sciences and Education Research, 2 (1), 116-130.

\begin{tabular}{|c|c|c|c|c|c|c|}
\hline 15. & $\begin{array}{l}\text { Using efficient strategies of critical assessment and analysis } \\
\text { of scientific literature }\end{array}$ & 4.7 & 21.9 & 73.3 & 3.99 & 0.89 \\
\hline 16. & Introducing changes in the teaching plan and program & 9.1 & 17.7 & 73.2 & 3.95 & 1.04 \\
\hline 17. & Leading teams and individuals & 5.9 & 21.2 & 73.0 & 3.94 & 0.88 \\
\hline 18. & Defining ethical values of the institution/department/course & 10.2 & 19.7 & 70.0 & 3.89 & 1.02 \\
\hline 19. & $\begin{array}{l}\text { Applying various methods of teaching harmonized with } \\
\text { learning results }\end{array}$ & 6.3 & 23.3 & 70.4 & 3.89 & 0.90 \\
\hline 20. & $\begin{array}{l}\text { Applying various procedures of assessment and evaluation } \\
\text { of students' success harmonized with learning results }\end{array}$ & 6.6 & 23.8 & 69.6 & 3.87 & 0.91 \\
\hline 21. & Creating teaching plans and syllabus & 10.3 & 17.6 & 72.0 & 3.86 & 0.99 \\
\hline 22. & $\begin{array}{l}\text { Understanding and the application of theories that learning } \\
\text { and teaching processes are based on }\end{array}$ & 7.6 & 22.6 & 69.9 & 3.86 & 0.92 \\
\hline 23. & Applying active learning techniques in the teaching process & 9.4 & 26.7 & 63.9 & 3.77 & 0.97 \\
\hline 24. & $\begin{array}{l}\text { Introducing innovations and changes in the work of the in- } \\
\text { stitution/department/course }\end{array}$ & 11.4 & 23.9 & 64.8 & 3.76 & 1.03 \\
\hline 25. & $\begin{array}{l}\text { Implementing review procedures in one's own research } \\
\text { field }\end{array}$ & 18.9 & 15.0 & 66.1 & 3.75 & 1.29 \\
\hline 26. & $\begin{array}{l}\text { Knowledge in the field of research methodology and statis- } \\
\text { tical data processing }\end{array}$ & 10.3 & 26.7 & 63.0 & 3.74 & 0.99 \\
\hline 27. & $\begin{array}{l}\text { Familiarity with negotiation and conflict resolution princi- } \\
\text { ples }\end{array}$ & 10.0 & 27.0 & 63.0 & 3.71 & 0.94 \\
\hline 28. & $\begin{array}{l}\text { Monitoring and advising younger colleagues in relation to } \\
\text { research work }\end{array}$ & 16.6 & 20.6 & 62.7 & 3.67 & 1.15 \\
\hline 29. & $\begin{array}{l}\text { Monitoring and advising younger colleagues in relation to } \\
\text { teaching work }\end{array}$ & 19.7 & 20.8 & 59.4 & 3.56 & 1.21 \\
\hline 30. & $\begin{array}{l}\text { Implementation of projects which are significant in terms of } \\
\text { community's needs }\end{array}$ & 16.4 & 28.8 & 54.8 & 3.54 & 1.06 \\
\hline 31. & $\begin{array}{l}\text { Identifying and monitoring recent changes in educational } \\
\text { and research policies }\end{array}$ & 15.4 & 35.6 & 49.1 & 3.43 & 1.00 \\
\hline 32. & Using e-learning and its integration in teaching & 26.0 & 25.5 & 48.6 & 3.31 & 1.23 \\
\hline 33. & $\begin{array}{l}\text { Familiarity and the application of fundamental legal docu- } \\
\text { ments (acts, regulations...) in the area of research and } \\
\text { higher education }\end{array}$ & 21.6 & 33.5 & 45.0 & 3.29 & 1.05 \\
\hline 34. & $\begin{array}{l}\text { Encouraging students to participate in volunteer programs } \\
\text { and programs that contribute to the development of the } \\
\text { community }\end{array}$ & 25.1 & 31.1 & 43.9 & 3.26 & 1.17 \\
\hline 35. & $\begin{array}{l}\text { Familiarity with program/project management (writing, ap- } \\
\text { plying and managing programs/projects) }\end{array}$ & 25.2 & 32.0 & 42.7 & 3.24 & 1.16 \\
\hline 36. & Familiarity with strategic planning principles & 24.2 & 32.7 & 43.1 & 3.23 & 1.06 \\
\hline 37. & $\begin{array}{l}\text { Familiarity with financing opportunities for projects in the } \\
\text { field of one's own research interest }\end{array}$ & 24.5 & 34.0 & 41.6 & 3.23 & 1.10 \\
\hline 38. & $\begin{array}{l}\text { Participation in the volunteer and philanthropic programs } \\
\text { and activities in the community }\end{array}$ & 27.8 & 30.8 & 41.4 & 3.20 & 1.17 \\
\hline 39. & Creating and maintaining (international) research networks & 29.9 & 29.2 & 40.9 & 3.16 & 1.21 \\
\hline 40. & $\begin{array}{l}\text { Cooperation with the public sector and economy (institu- } \\
\text { tions and companies from the related field) }\end{array}$ & 32.2 & 26.2 & 41.6 & 3.11 & 1.26 \\
\hline 41. & Having basic knowledge about intellectual ownership & 28.3 & 35.1 & 36.6 & 3.09 & 1.11 \\
\hline 42. & $\begin{array}{l}\text { Participating in pubic discussions of general social im- } \\
\text { portance from the professional perspective }\end{array}$ & 29.6 & 34.8 & 35.6 & 3.07 & 1.12 \\
\hline 43. & $\begin{array}{l}\text { Managing financial resources of the institution/depart- } \\
\text { ment/course }\end{array}$ & 34.5 & 26.2 & 39.3 & 3.04 & 1.28 \\
\hline 44. & Cooperation with the civil sector & 34.2 & 32.0 & 33.7 & 2.94 & 1.16 \\
\hline 45. & $\begin{array}{l}\text { Adjustment of the teaching process to students with special } \\
\text { needs }\end{array}$ & 37.5 & 31.0 & 31.6 & 2.89 & 1.19 \\
\hline
\end{tabular}

The first two competencies ranked as most important ones are also competencies emphasized in the list of competencies for lifelong learning in the European Framework of Key Competencies 
Turk, M., Ledić, J. (2016). Croatian academics' attitudes on the importance of academic profession competencies. International Journal of Social Sciences and Education Research, 2 (1), 116-130.

for Lifelong Learning (2004). The Framework describes general IT literacy in the context of digital competency, where it states that it involves the confident and critical use of electronic media for work, leisure and communication. The Framework also emphasizes that general IT literacy is connected with logical and critical thinking, high-level of information management skills and well developed communication skills. Communication in the mother tongue as "... the ability to express and interpret concepts, thoughts, feelings, facts and opinions in both oral and written form (listening, speaking, reading and writing), and to interact linguistically in an appropriate and creative way in a full range of societal and cultural contexts - in education and training, work, home and leisure." (European Reference Framework of Key Competencies for Lifelong Learning, 2007, 8 ) is another of the eight key competencies listed in the Framework and can be considered an unavoidable competency in the everyday social and academic environment. From displayed data, it is evident that Croatian academics, apart from general (academic) competencies, perceive the traditional academic teaching and research competencies as most important for performing the role of an academic. A review of these competencies reveals that competencies in question form the basis of teaching (Planning and carrying out teaching) or research (Familiarity with the basic principles of scientific writing and publishing and Using efficient strategies of searching through research and profession-related literature) work. Authors who examine teaching competencies and higher education (Smith, 2001; Lammers \& Murphy, 2002; Kroeber, 2007; Taylor, 2010; Donaldson, 2013) highlight the competency of planning and carrying out teaching as fundamental in terms of familiarity with the teaching process or as a fundamental characteristic of good/highly competent teacher. Likewise, the familiarity with the basic principles of scientific writing and publishing can be considered a precondition for the successful performance of research activities, especially at the beginning of their research careers (Vizek Vidović, Brajdić Vuković \& Matić, 2014).

Unlike the mentioned ones, the following competencies were evaluated by respondents as least important: Having basic knowledge about intellectual ownership $(\mathrm{M}=3.09, \mathrm{SD}=1.11)$; Participating in pubic discussions of general social importance from the professional perspective $(M=3.07$, $\mathrm{SD}=1.12)$; Managing financial resources of the institution/department/course $(\mathrm{M}=3.04$, $\mathrm{SD}=1.28)$; Cooperation with the civil sector $(\mathrm{M}=2.94, \mathrm{SD}=1.16)$; and Adjustment of the teaching process to students with special needs $(\mathrm{M}=2.89, \mathrm{SD}=1.19)$.

Results presented reveal that the least important competencies come from all groups of competencies - one from general academic competencies (Having basic knowledge about intellectual ownership), one from leadership in higher education (Managing financial resources of the institution/department/course), one from teaching competencies (Adjustment of the teaching process to students with special needs), while two competencies, based on the theoretical analysis, belong to third mission competencies (Participating in public discussions of general social importance from the professional perspective and Cooperation with the civil sector).

The results that indicate that third mission competencies were evaluated as being of little importance, in the context of research findings are not surprising since the third mission of universities in the national environment is a concept whose implementation began recently (Ledić, 2007; Ćulum 2012; Ćulum \& Ledić, 2010; 2011). The results of conducted research studies suggest that Croatian academics do not recognize the concept of the third mission and show a relatively low sensibility to it. They also reveal significant lack of educational contents required for its understanding, as well as insufficient involvement of the concept of the third mission in the core academic activities - teaching and research (Ćulum, 2012; 2013; Ćulum \& Ledić, 2011). However, 
Turk, M., Ledić, J. (2016). Croatian academics' attitudes on the importance of academic profession competencies. International Journal of Social Sciences and Education Research, 2 (1), 116-130.

although recognized at the level of policy documents ${ }^{1}$, the results of this research partially confirm previous research findings, revealing that the implementation of this concept in the academic community is still incomplete. To elaborate, based on the evaluation of importance, the third mission competencies are ranked low, that is, between 30th and 45th place, with the exception of competency relating to the education of students as social responsible and active citizens. These results imply that academics (still) don't sufficiently recognize the importance of this concept and acknowledge the need for stronger and systematic implementation of the third mission activities in the academic community in Croatia as well as the need for considering other possible models and ways of acquiring third mission competencies by academics. Especially surprising, even worrying, is the rank of the competency Adjustment of the teaching process to students with special needs $(\mathrm{M}=2.89, \mathrm{SD}=1.19)$. Based on their evaluation of its importance, academics in Croatia perceive this competency as least important of all proposed competencies of the academic profession. The question of students with special needs is a part of the problem of equal opportunities in the context of discussions on the access to higher education which is analysed and examined within the framework of social dimensions in education. In this context, it is implied that higher education institutions must play an important role in the reduction of social inequalities by encouraging greater inclusion of students from vulnerable social groups and by removing barriers they encounter with regards to their access to and completion of studies (Farnell \& Kovač, 2011) ${ }^{2}$.

It can, therefore, be assumed that academics are not sufficiently sensitive to the issues of students/people with special needs, and in this context it is possible to raise the question of Croatian academics' awareness of the social dimension. It is possible, therefore, to raise questions whether academics are prepared to adjust their teaching process to students with special needs, do they possess necessary awareness and sensitivity towards special social groups and whether, in that context, they are able to prepare socially sensitive and socially responsible students.

\section{Final thoughts}

By positioning the role of academics in the wider context of changes and demands for (re)defining the competencies of the academic profession, the aim of the presented research was to examine the attitudes of Croatian academics on the importance of academic competencies needed for the successful accomplishment of their academic activities at the start of their senior academic career.

The results of conducted research indicate that academics don't observe the importance of academic profession competencies strictly within the framework of a given academic discourse, that is, through core academic activities - teaching and research, but in a much broader context and in line with the recommendations of numerous policy documents at the international level.

\footnotetext{
${ }^{1}$ It should be noted that the concept of the third mission of universities experienced a significant recognition in the period between the findings of conducted research studies (Ćulum, 2010; 2013; Ćulum \& Ledić, 2011) and today, in the form of the latest document on the development of science and higher education on the national level and that is the Croatian Strategy for Education, Science and Technology (2013). Recognised in the Strategy as one of the measures is that - "The third mission is becoming an ever more articulated duty of higher education institutions. It includes a number of activities and engagements aimed at developing and improving economic, cultural and civil life, and includes an integrative concept of cooperation according to which the university is obligated to contribute to all sectors of society, as well as the civic mission of the university oriented towards educating socially responsible and active citizens" (Croatian Strategy for Education, Science and Technology, 2013, 108-109).

${ }^{2}$ Research results (Cvitan et al., 2011) reveal that $68 \%$ of students who indicated that they encounter people with physical or mental disabilities during their studies, claimed that not enough or only partial attention is paid to problems of such students.
} 
Turk, M., Ledić, J. (2016). Croatian academics' attitudes on the importance of academic profession competencies. International Journal of Social Sciences and Education Research, 2 (1), 116-130.

However, the results revealed that the concept of the third mission was evaluated as being of little importance. In this context, it would be necessary to additionally explore possible mechanisms for the better implementation of the third mission concept in the core academic activities, in line with the findings of earlier research studies on the attributes of academics who are better prepared for the integration of the third mission (Ćulum, 2012).

Of particular concern is the result that reveals a low level of sensibility to the problems of students/people with special needs, in the context of which it is possible to discuss the issue of Croatian academics' awareness of the social dimension. Since this research study could not determine the implications of such an attitude, in the context of discussions on the social dimension in higher education it would be necessary to examine the level of sensibility of academics to people/students with special needs and to identify the authentic reasons for such attitudes.

In addition to the specific topics connected with particular competencies, this research study also provoked the discussion on the academic profession competencies in the national academic area. Following the results of this research, and in order to acknowledge the competencies of the academic profession in the wider frameworks of educational policies, it would be important to examine the readiness and support of its (current) creators regarding the competencies approach as an important element in the planning of development activities and the promotion of the academic profession.

\section{References}

Altbach, P. G. (2000). The Deterioration of the Academic Estate: International Patterns of Academic Work. In Altbach, P. G. (Eds.), The Changing Academic Workplace: Comparative Perspectives, New York: Boston College Center for International Higher Education, 1-24

Altbach, P. G. (2002). Centers and peripheries in the academic profession: The special challenges of developing countries. In Altbach, P. G. (Eds.), The Decline of the Guru: The Academic Profession in Developing and Middle-Income Countries, New York: Boston College Center for International Higher Education and Palgrave Publishers, 1-22

Altbach, P. G., Davis, T. M. (1999). Global Challenge and National Response: Notes for an International Dialogue on Higher Education. In Altbach, B., P., Peterson, Mc., P. (Eds.). Higher Education in the 21st Century: GLOBAL CHALLENGE AND NATIONAL RESPONSE, 3-10, Institute of International Education. Retrieved 20.11.2012. from: http://www.iie.org/en/Research-and-Publications/Publications-and-Reports/IIE-Bookstore/RR29-Higher-Education-in-the-21st-Century-Global-Challenge-and-National-Response

Altbach, P. G., Reisberg, L., Rumbley, L. E. (2009). Trends in Global Higher Education: Tracking an Academic Revolution. A Report Prepared for the UNESCO 2009 World Conference on Higher Education. Paris: UNESCO

Arbo, P., Benneworth, P. S. (2006). Understanding the regional contribution of higher education institutions: a literature review. IMHE ‘The Regional Contribution of Higher Education' project report, Paris: OECD.

Beards, M., Edwards, M., Sheik, M. (2009). The secret of high productivity in the research lab. What drives research productivity? An understanding of how the world's most successful laboratories operate reveals some answers. In Zemmel, R., Sheik, M. (Eds.). Invention reinvented, 7-14, Geneve: McKinsey \& Company. Retrieved 1.6.2014. from: http://www.mckinsey.com

Benneworth, P. S., Hospers, G. (2007). Urban competitiveness in the knowledge economy: Universities as new planning animateurs', Progress in Planning, 67, 105-197. 
Turk, M., Ledić, J. (2016). Croatian academics' attitudes on the importance of academic profession competencies. International Journal of Social Sciences and Education Research, 2 (1), 116-130.

Bess, J. L. (1998). Teaching well: Do you have to be schizophrenic?. The Review of Higher education, 22, 1, 1-15

Boyer, E. L. (1990). Scholarship reconsider: priorities of the professoriate. Stanford, CA: The Carnegie Foundation for the Advancement of Teaching.

Boyer, E. L. (1996). The Scholarship of Engagement. Journal of Public Service and Outreach, 1, 1, 11-20.

Brajdić Vuković, M. (2012). Akteri profesionalne socijalizacije mladih istraživača u prirodnim i društvenim znanostima. Unpublished PhD thesis. Zagreb: Filozofski fakultet u Zagrebu

Brajdić Vuković, M. (2013). Aktualni problemi profesionalne socijalizacije u novačkom sustavu: slučaj prirodnih i društvenih znanosti. Revija za socijalnu politiku, 20, 2, 99-122.

Braxton, J. M. (1993). Selectivity and rigor in research universities. Journal of Higher Education, 64, 657675

Brennan, J., King, R., Lebeau, Y. (2004). The Role of Universities in the Transformation of Societies. Association of Commonwealth Universities and Centre for Higher Education Research and Information. London: The Open University.

Brew, A. (2006). Research and Teaching. Beyond the Divide. New York: Palgrave Macmillan

Burkard, A., Cole, D. C., Ott, M., Stoflet, T. (2005). Entry-level competencies of new student affairs professionals: A delphi study. NASPA Journal, 42, 3, 1-17

Cantor, N. (2010). Academic Excellence and Civic Engagement: Constructing a Third Space for Higher Education. Office of the Chancellor. Paper 1; Retrieved 7.5.2010. from: http://surface.syr.edu/chancellor/1

Colbeck, C. L. (2002). Integration: Evaluating faculty work as a whole. New Directions for Institutional Research, 114, 43-52.

Crosthwaite, C. (2010). Managerial leadership competencies of heads of departments: a case study of higher educational institutions in Kerala. Neobjavljena doktorska disertacija. Queensland: School of Management and Marketing, University of Southern Queensland. Retrieved 15.9.2014. from: http://eprints.usq.edu.au/18827/

Cvitan, M., Doolan, K., Farnell, T., Matković, T. (2011). Socijalna i ekonomska slika studentskog života u Hrvatskoj: nacionalno izvješće istraživanja EUROSTUDENT za Hrvatsku. Zagreb: Institut za razvoj obrazovanja

Ćulum, B. (2009). Analiza i projekcija razvoja civilne misije sveučilišta u Hrvatskoj. Unpublished MA thesis, Rijeka: Filozofski fakultet u Rijeci.

Ćulum, B. (2012). Izazovi treće misije sveučilišta. In Ledić, J. (Eds.). Promjene u akademskoj profesiji: odgovor na izazove u društvu?, 23-39, Rijeka: Filozofski fakultet u Rijeci

Ćulum, B., Ledić, J. (2010). Civilna misija sveučilišta: element u tragovima?. Rijeka: Filozofski fakultet u Rijeci

Ćulum, B., Ledić, J. (2011). Sveučilišni nastavnici i civilna misija sveučilišta. Rijeka: Filozofski fakultet u Rijeci

Ćulum, B., Rončević, N., Ledić, J. (2013). The Academic Profession and the Role of the Service Function. In Teichler, U., Höhle, E. A. (Eds.). The Work Situation of the Acedemic Profession in Europe: Findings of a Survey in Twelve Countries, 137-158, Heidelberg: Springer

Dávila Quintana, C. D., Mora Ruiz, J-G., Vila Lladosa, L. E. (Septmeber, 2011). Promoting Leadership Competencies in Higher Education. Paper at the DEHEMS Conference, Vienna. Retrieved 14.10.2013. from: 
Turk, M., Ledić, J. (2016). Croatian academics' attitudes on the importance of academic profession competencies. International Journal of Social Sciences and Education Research, 2 (1), 116-130.

http://www.dehems-project.eu/static/uploaded/files/files/contributions/Davila_Quintana_Carmen_Delia_DEHEMS_Conference_Paper_Promoting_Leadership_Competencies_in_Higher_Education.pdf

Deem, R. (2001). Globalisation, New Managerialism, Academic Capitalism and Entrepreneurialism in Universities: is the local dimension still important. Comparative Education, 37, 1, 7-20

Donaldson, M. L. (2013). Principals' approaches to cultivating teacher effectiveness: Constraints and opportunities in hiring, assigning, evaluating, and developing teachers. Educational Administration Quarterly, $49,5,838-882$.

Elton, L. (1986). Research and Teaching: Symbiosis or conflict?. Higher Education, 15, 34, $299-304$.

Elton, L. (1992). Research, teaching and scholarship in an expanding higher education system. Higher Education Quarterl, 46, 3, 252-267.

Elton, L. (2001). Research and Teaching: Conditions for a Positive Link. Teaching in Higher Education, 6, 1, 43-56.

Europska komisija (2004). Common European Principles for Teacher Competences and Qualifications. Retrieved 4.2.2013. from: http://www.see-educoop.net/education_in/pdf/01-en_principles_en.pdf

Europska komisija (2012). Supporting the Teaching Profession s for Better Learning Outcomes. Retrieved 4.2.2013. from: http://eur-lex.europa.eu/LexUriServ/LexUriServ.do?uri=SWD:2012:0374:FIN:EN:PDF

Farnell, T., Kovač, V. (2011). Uklanjanje nepravednosti u visokom obrazovanju: prema politici »proširivanja sudjelovanja« u Hrvatskoj. Revija za socijalnu politiku, 17, 2, 257-275

Farnell, T., Matković, T., Doolan, K., Cvitan, M. (2013). Socijalna inkluzivnost visokog obrazovanja u Hrvatskoj: analiza stanja. Zagreb: Institut za razvoj obrazovanja

Fumasoli, T., Goastellec, G. (2015). Global models, disciplinary and local patterns in academic recruitment processes. In Kehm, B., Goastellec, G., Fumasoli, T. (Eds.). The Changing Academy - The Changing Academic Profession in International Comparative Perspective, 69-94, Springer: Heidelberg

Goddard, J. B., Chatterton, P. (2003). The response of universities to regional needs'. In Boekema, F., Kuypers, E., Rutten, R. (Eds.) (2003). Economic Geography of Higher Education: Knowledge, Infrastructure and Learning Regions, 19-41, London: Routledge.

Hénard, F., Roseveare, D. (2012). Fostering Quality Teaching in Higher Education: Policies and Practices. OECD. Retrieved 15.2.2013. from:: http:/www.oecd.org/edu/imhe/QT\%20policies\%20and\%20practices.pdf

Hoff, K. S. (1999). Leaders and managers: Essential skills required within higher education. Higher Education, 38, 3, 311-331

Höhle, E. A., Teichler, U. (2013). The Academic Profession in the Light of Comparative Surveys. In Kehm, B., Teichler, U. (Eds.). The Academic Profession in Europe: New Tasks and New Challenges, 23-38, London: Springer

Inlow, G. M. (1956). Is Teaching Profession?. The School Review, 64, 6, 256-259

Kalin, B. (2004). O nastavničkoj kompetenciji sveučilišnih nastavnika. Metodički ogledi, 11, 1, 43-62

Kelly, K., Murphy, M. (2007). Academic Change ih Higher Education in Europe. Proceedings of the Annual Conference ASEE (American Society for Engineering Education)

Kelly, M., Grenfell, M. (2004). European Profile for Language Teacher Education. A Frame of Reference. UK: University of Southampton 
Turk, M., Ledić, J. (2016). Croatian academics' attitudes on the importance of academic profession competencies. International Journal of Social Sciences and Education Research, 2 (1), 116-130.

Kelly, M., Grenfell, M., Gallagher-Brett, A., Jones, D., Richard, L., Hilmarsson-Dunn A. (2002). The Training of Teachers of a Foreign Language: Developments in Europe. A Report to the European Commission DG Education and Culture. UK: University of Southampton

Knight, P. (1995). Assessment for Learning in Higher Education. London: Kogan Page

Kogan M., Teichler U. (Eds.) (2007.) Key Challenges to the Academic Profession. Kassel: International Centre for Higher Education Research, University of Kassel

Koster, B., Dengerink, J. J. (2008). Professional standards for teacher educators: how to deal with complexity, ownership and function. Experiences from the Netherlands. European Journal of Teacher Education, 31, 2, 135-149

Kovač, V. (1996). Diskusija kao nastavna metoda u visokoškolskoj nastavi: prilog za poticanje dubinskog pristupa učenju. Napredak, 137, 4, 433-440.

Kovač, V. (2001). Osposobljavanje i usavršavanje sveučilišnih nastavnika. Rijeka: Filozofski fakultet u Rijeci

Kovač, V. (2004). Koncepcije upravljanja visokoškolskim institucijama kao podrška uvođenju sustava osiguranja kvalitete. Unpublished PhD thesis. Rijeka: Filozofski fakultet u Rijeci

Kovač, V., Ledić, J., Rafajac, B. (2002). Upravljanje visokoškolskim institucijama: problemi i pristupi rješenjima. Društvena istraživanja, 11, 6, 1013-1030

Kovač, V., Ledić, J., Rafajac, B. (2003). Academic Staff Participation in University Governance: Internal Responses to External Quality Demands. Tertiary Education and Management, 9, 3, 215-232

Kovač, V., Ledić, J., Rafajac, B. (2007). Trendovi i izazovi teorije i prakse upravljanja sveučilištima. Časopis za visoko obrazovanje, 1, 1, 55-68

Kreber, C. (2007). What's it really all about? The scholarship of teaching and learning as an authentic practice. International Journal of the Scholarship of Teaching and Learning, 1, 1, 1-4

Kuh, D. G., Hu, S. (2001). Learning Productivity at Research Universities. The Journal of Higher Education, $72,1,1-28$.

Lamblin, P., Etienne, C. (Eds.) (2010). Skills and competencies needed in the research field objectives 2020. APEC i DELLOITE. Retrieved 15.2.2013. from: http://www.eurocadres.org/IMG/pdf/APEC_EN_Skills_and_competencies_needed.pdf

Lammers, W. J., Murphy, J. J. (2002). A profile of teaching techniques used in the university classroom. Active Learning in Higher Education, 3, 1, 54-67

Lazibat, T. (2005). Sustavi upravljanja kvalitetom u visokom obrazovanju. Zagreb: Sinergija nakladništvo d.o.o.

Ledić, J. (1994). TQM - novi pristup kvaliteti visokog obrazovanja. Napredak, 135, 4, 456-465.

Ledić, J. (2007). U potrazi za civilnom misijom hrvatskih sveučilišta. In Previšić, V., Šoljan, N. N., Hrvatić, N. (Eds.). Pedagogija - prema cjeloživotnom obrazovanju i društvu znanja, 1, 123-134, Zagreb: Hrvatsko pedagogijsko društvo

Ledić, J. (2009). Potiču li sveučilišni nastavnici prezir spram obrazovanja za nastavničku profesiju. Presentation „Predvisokoškolsko obrazovanje: Hrvatski kvalifikacijski okvir, naukovna osnova i izobrazba nastavnika i učitelja“, Zagreb: Hrvatska akademija znanosti i umjetnosti. Retrieved 7.5.2012. from http://info.hazu.hr/upload/file/HKO/Jasminka\%20Ledic.pdf

Ledić, J. (2012) (Eds.). Promjene u akademskoj profesiji: odgovor na izazove u društvu?. Rijeka: Filozofski fakultet u Rijeci 
Turk, M., Ledić, J. (2016). Croatian academics' attitudes on the importance of academic profession competencies. International Journal of Social Sciences and Education Research, 2 (1), 116-130.

Locke, W., Teichler, U. (Eds.) (2007). The Changing Conditions for Academic Work and Careers in Selected Countries. Kassel: International Centre for Higher Education Research, University of Kassel.

Macfarlane, B. (2005). Placing service in academic life. In Barnett, R. (Eds.). Reshaping the university: New relations between research, scholarship and teaching, 165-177, Berkshire: Open University Press.

Macfarlane, B. (2007). Defining and rewarding academic citizenship: The implications for university promotions policy. Journal of Higher Education Policy and Management, 29(3), 261-273

Marton, F. (2007). Towards a a pedagogical theory of learning. In Entwistle, N., Tomlinson, P. (Eds.). Student learning and university teaching, 19-30, Leicester: British Psychological Society

McInnis, C. (2000). Changing academic work roles: the everyday realities challenging quality in teaching. Quality in Higher Education, 6, 2, 143-152.

Munjiza, E., Lukaš, M. (2006). Pedagoško-psihološko osposobljavanje učitelja u visokoškolskim ustanovama. Odgojne znanosti, 8, 2, 361-383

Musselin, C. (2007). Transformation of academic work: Facts and analysis. In Kogan, M., Teichler, U. (Eds.). Key challenges to the academic profession, 175-190, Kassel: International Centre for Higher Education Research Kassel

Neave, G. (1983). The Changing Face of the Academic Profession in Western Europe. European Journal of Education, 18, 3, 217-227

Nelson, M. R. (2003). The CIO in Higher Education: Leadership, Competencies, Effectiveness. Research Bulletin, 22, 1-13. Retrieved 1.9.2014. from https://net.educause.edu/ir/library/pdf/ERB0322.pdf

OECD (2005). Teachers matter: attracting, developing and retaining effective teachers. Retrieved from 24.8.2014. http://www.oecd.org/education/school/attractingdevelopingandretainingeffectiveteachersfinalreportteachersmatter.htm

Potgieter, I., Basson, J., Coetzee, M. (2011). Management competencies for the development of heads of department in the higher education context: a literature overview. South African Journal of Labour Relations, 35, 1, 81-103

Purcell, W. (2008). Balancing the Needs and Expectations of Society with the Autonomy of Higher Education Institutions. Retrieved 1.06.2012. from http://skrati.com/nhmtpzj

Puzić, S., Doolan, K., Dolenece, D. (2006). Socijalna dimenzija "Bolonjskog procesa" i (ne)jednakost šansi za visoko obrazovanje: neka hrvatska iskustva. Sociologija i prostor, 172/173, 2/3, 243-260

Rački, Ž, Peko, A., Varga, R. (2010). Necessity of Lifelong Education of University Teachers: PedagogicalPsychological and Didactic-Methodological Training. Modszertani Kozlony, 1, 1, 36-49

Ramsden, P., Moses, I. (1992). Associations between Research and Teaching in Australian Higher Education. Higher Education, 23, 3, 273-295.

Rychen, D. S. (2004). An overarching conceptual framework for assessing key competences in an international context. Lessons from an interdisciplinary and policy-oriented approach. In Descy, P.; Tessaring, M. (Eds.). The foundations of evaluation and impact research. Third report on vocational training research in Europe: background report. Luxembourg: Office for Official Publications of the European Communities. retrieved 17.1.2013. from: www.cedefop.europa.eu/files/BgR1_Rychen.pdf

Spendlove, M. (2007). Competencies for effective leadership in higher education. International Journal of Educational Management, 21, 5, 407-417

Taylor, M. C. (2010). Crisis on Campus. A Bold Plan for Reforming Our Colleges and Universities. New York: Alfred A. Knopf 
Turk, M., Ledić, J. (2016). Croatian academics' attitudes on the importance of academic profession competencies. International Journal of Social Sciences and Education Research, 2 (1), 116-130.

Teichler, U. (1996). The conditions od the academic profession: an international, comparative analysis of the academic profession in Western Europe, Japan and the USA. In Maassen, P. A. M., Vught van F. A. (Eds.). Inside academia: new challenges of the academic profession, 15-65, Utrecht: De Tijdstroom

Turk, M. (2015). Academic Profession in Europe: Changes and Challenges, In Teaching, Learning, and Research in the "Just Google It" Age, 5, 1, 449-466, University of Harvard, Boston, USA: 21st Century Academic Forum. Retrieved 15.11.2015. from http://bib.irb.hr/prikazi-rad?\&rad=777900

UNESCO (2005). Towards Knowledge Societies. Paris: UNESCO. Retrieved 12.3.2014. from http://unesdoc.unesco.org/images/0014/001418/141843e.pdf

Vizek Vidović, V. (2009). Planiranje kurikuluma usmjerenoga na kompetencije u obrazovanju učitelja i nastavnika. Zagreb: Filozofski fakultet Sveučilišta u Zagrebu i Učiteljski fakultet Sveučilišta u Zagrebu

Vizek Vidović, V., Brajdić Vuković, M., Matić, J. (2014). IDIZ-ov priručnik za mentoriranje mladih istraživača. Zagreb: Institut za društvena istraživanja. 